\title{
ОПРЕДЕЛЕНИЕ ВЛАГИ В ПОЛИМЕРНЫХ МАТЕРИАЛАХ
}

\author{
E. HEINSOO, Aili KOGERMAN, O. KIRRET. NIISKUSE MAARAMINE POLUMEERSETES \\ MATERJALIDES \\ E. HEINSOO, Aili KOGERMAN, O. KIRRET. DETERMINATION OF MOISTURE IN THE POLY- \\ MER MATERIALS
}

Определение влажности полимеров представляет собой весьма важную и сложную проблему. Для этой цели применяют сложные и дорогостоящие аппараты (напр., масс-спектрометры), выдано немало патентов и авторских свидетельств на автоматические анализаторы влаги. Однако в практической работе чаще пользуются классическим весовым методом. Навеску полимера высушивают при $105^{\circ} \mathrm{C}$ до постоянного веса, взвешивая ее через каждые несколько часов. Этот метод точный, но занимает много времени (10-12 ч).

Нами предлагается простой и быстрый метод определения влажности полимеров, основанный на применении принципов и аппаратуры ступенчатой пиролизной газовой хроматографии (СПГХ) [ $\left.{ }^{1}\right] \ldots \ldots$

Аппаратура состоит из пиролизатора, газового хроматографа и желательно еще интегратора. Колонка хроматографа может быть любой, главное к ней требование - симметричность пика воды (в наших опытах использован полимерный сорбент «Сепарон CHN»).

Образец массой 5-10 мг помещают в пиролизатор и подвергают импульсному нагреву при температуре $100^{\circ}$ и хроматографически определяют количество воды. Далее температуру поднимают на $10^{\circ}$ и іроводят новый анализ. Эту процедуру повторяют до исчезновения пика воды на хроматограмме. Обычно для этого достаточно 6-8 нагреваний (температура последнего импульса $160-180^{\circ}$ ). Появление на хроматограмме какого-нибудь другого пика наряду с пиком воды указывает на начало термодеструкции полимера, В таком случае следует повторить анализ, ступенчато поднимая температуру не на $10^{\circ}$, а меньше, например, на $5^{\circ}$ или на $2^{\circ}$. Таким способом достигается полное высушивание материала при более низкой температуре. Если изве́стна температура начала термодеструкции полимера, можно все импульсные нагревы проводить и при одной температуре - на $30-40^{\circ}$ ниже начала разложения полимера.

Данные таблицы показывают, что метод СПГХ позволяет получить довольно хорошо репродуцируемые и сопоставимые с весовым методом результаты. Две серии опытов с шерстью были проведены в разные дни в целях выяснения, насколько влажность воздуха влияет на содержание влаги в полимерах.

Однопиковая хроматограмма допускает использование довольно коротких хроматографических колонок, позволяющих проводить нагревы через каждые $2-2,5$ мин. Общее время анализа не превышает $15-20$ мин. 
Содержание влаги в полимерных материалах, вес. \%

\begin{tabular}{|c|c|c|c|c|}
\hline \multirow[b]{2}{*}{ Полимер } & \multicolumn{3}{|c|}{ Метод СПГХ } & \multirow[b]{2}{*}{$\begin{array}{c}\text { Весовой } \\
\text { метод }\end{array}$} \\
\hline & $\begin{array}{c}\text { Конечная } \\
\text { температура } \\
\text { образца, }{ }^{\circ} \mathrm{C}\end{array}$ & Опыт 1 & Опыт 2 & \\
\hline $\begin{array}{l}\text { Шерсть I } \\
\text { Шерсть II } \\
\text { Нитрон } \\
\text { Капрон } \\
\text { Винол } \\
\text { Хлопок } \\
\text { Вискоза }\end{array}$ & $\begin{array}{l}190 \\
190 \\
140 \\
170 \\
160 \\
190 \\
200\end{array}$ & $\begin{array}{l}6,605 \\
8,306 \\
0,906 \\
1,609 \\
1,904 \\
4,992 \\
8,260\end{array}$ & $\begin{array}{l}6,332 \\
8,027 \\
0,763 \\
1,677 \\
2,181 \\
4,957 \\
8,505\end{array}$ & $\begin{array}{l}8, \overline{24} \\
0,92 \\
1,65 \\
2,15 \\
5,05 \\
8,55\end{array}$ \\
\hline
\end{tabular}

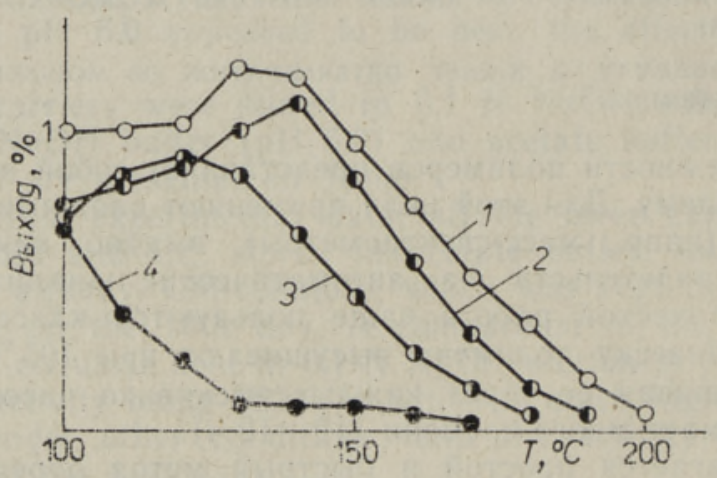

Выделение воды из вискозы (1), шерсти (2), хлопка (3) и капрона (4).

Методом СПГХ можно определять содержание воды не только в полимерных, но и в других твердых материалах - например, в растительных и животных тканях, в горных породах и т. д.

Предлагаемый метод особенно удобен при исследовании термодеструкции различных материалов. Так, можно одновременно определить первоначальное содержание влаги в материале и высушить его (см. рисунок), чтобы вода не искажала результатов исследования пиролиза.

В полимерных материалах можно определять таким способом не только влажность, но и содержание остаточных непрореагировавших мономеров, температуры кипения которых обычно явно ниже температур начала термодеструкций соответствующих полимеров.

ЛИТЕ РА Т У РА

1. Heinsoo, E., Kogerman, A., Kirret, O., Coupek, J., Vilkova, S. Stepwise pyrolysisgas chromatography of viscose fibres. - J. Anal. Appl. Pyrol., 1980, 2, N 2, 131-139.

Институт химии

Академии наук Эстонской ССР
Поступила в редакцию 1/VI 1984 